\title{
Quantitative Risk Assesment of Crystalline Silica Exposure in Ceramics Industry
}

\author{
Moch.Sahri ${ }^{1}$, Abdul Rohim Tualeka ${ }^{1}$, Noeroel Wida jati \\ 'De partment of Occupational Health and Safety, Airlangga University, Surabaya, Indonesia
}

\begin{abstract}
Crystalline silica can be found in Ceramics Industry. Ceramics are basically made of clay, feldspar and silica sand. Ceramics manufacturing process starts from the processing of materials, forming, drying, burning and gazing. Crystalline silica consists of three types of quartz, tridymite and cristobalite which are distinguished by their forming temperature. Crystaline silica dust is very dangerous for health workers are exposed continuously it can cause a silicosis. Prevention and control efforts can be done one of them by conducting a risk analysis study on crystalline silica exposure. In this research will be discussed about the analysis of crystalline silica exposure into production workers in the ceramics industry.

The purpose of this study was to assess the risk level of crystalline silica due to silicosis. Subjects in this study were 47 production workers with the exposure to crystalline silica between $0,007-0,4 \mathrm{mg} / \mathrm{m}^{3}$. From the result of risk analysis, it was found that $42,6 \%$ of workers had unsafe risk which was confirmed by radiology examination was $6,4 \%$ of workers with abnormal condition. Complaints experienced by workers include shortness of breath, cough and phlegm. Long term exposure to 5-20 years to the next tends to increase the risk of the effects caused by exposure to crystalline silica. Based on the results of this study it is recommended that decision makers take action to implement effective risk management strategies to prevent the long-term effects of crystalline silica exposure to the workplace.
\end{abstract}

Keywords: risk analysis, crystalline silica, ceramic industry

\section{INTRODUCTION}

Exposure to the existing hazards in the work environment in the ceramics industry most widely encountered is silica dust, total dust and heat pressure. Silica dust is the main pollutant in the ceramics industry because it is one part in the raw material. Crystalline silica is one of the most widely encountered minerals of the earth, with wide exposure in working environments and ambient environments's silica belongs to Group 1 substances that are carcinogenic in humans ${ }^{2}$ In China, the association with silica dust exposure and mortality from all causes of respiratory illness, respiratory tuberculosis, and cardiovascular disease is significant ${ }^{3 .}$ Worldwide estimated at least two to three million

\section{Correspoding author :}

Dr. Abdul Rohim Tualeka

Email : inzut.tualeka@gmail.com workers work roughly exposed to silica each year ${ }^{1}$. Silica crystal dust is inhaled from the work environment can cause pulmonary fibrosis (silicosis), decreased lung function, pulmonary inflammation, and lung cancer have been associated with glomerulonephritis and disorders of the liver, spleen, and immune system ${ }^{1}$. The prevalence of silicosis data varies from country to country. Studies conducted in the United States show that there is 3600 7300 new cases of silicosis per year in 1987-1996. Studies conducted at a cement plant found radiological silicosis suspicion of $0.5 \%{ }^{4}$. A study conducted at one of the cement plants in West Java showed that the incidence of silicosis was $2.06 \%$ in $1990-2003^{5}$. A previous study showed that $32 \%$ of ceramic material samples contains free silica throughout the Taiwan ${ }^{6}$

Several recent epidemiological studies have shown that the present value of standard silica dust are insufficient for guidelines to protect and prevent chronic silicosis ${ }^{6 .}$ The threshold value of crystalline silica dust 
in Indonesia is based on the Ministry of Manpower and Transmigration No. PER.13 / MEN / X / 2011 on the threshold value of physics and chemical factors in the workplace set at $0.05 \mathrm{mg} / \mathrm{m}^{3}$. Cases of pneumoconiosis ranked first Occupational Diseases (OD) in Japan and China $^{8}$. Based on the silicosis surveillance program in Ontario it was found that the incidence of silicosis was a significant increase in more than $8 \%$ of respondents after exposure to silica dust for 35 years ${ }^{9}$. The risk analysis approach is one way to determine the level of risk due to crystalline silica dust present or some future time making it possible for early prevention efforts.

\section{METHOD AND MATERIAL}

This type of research is descriptive research using quantitative analysis method. The study design used was a risk analysis method taken from risk analysis steps, risk management, and risk communication used to assess and predict the occurrence of health effects as a result the presence of a hazardous exposure to this case is exposure to crystalline silica. The design of this research is cross sectional where the environmental data collection (silica dust measurement) and taking of rontgen photo taken at same time period. The population of this study are all workers that work in the production section from the processing of raw materials to packing which amounted to 50 people. The sample of this study is the total population with the exclusion factor of workers not suffering and never exposed from tuberculosis, so the sample in this study amounted to 47 people. The measurement of crystalline silica dust in the working environment is based on NIOSH 7500 method of XRD ${ }^{10}$.

The risk is calculated based on the amount of intake of agent entering the worker's body so that it can be known how much the risk of health effects on workers. The data and information required to calculate the silica dust intake of the worker's body is all variables in the following ${ }^{11}$.

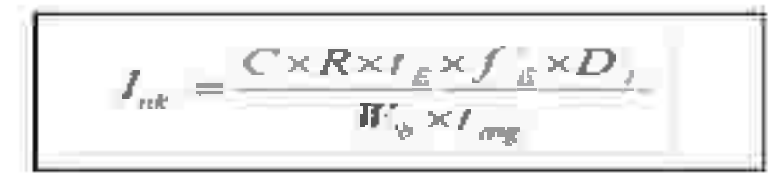

Level of risk to be expressed in Risk Quotien notation (RQ). To do risk characterization is done by comparing the intake of $\mathrm{Rfc}$ from the agent.

$$
R Q=\frac{I_{\alpha}}{R D D \text { sin } R \bar{L}}
$$

The Rfc value was obtained using the data onto Chen et al of $6 \mu \mathrm{g} / \mathrm{m} 33$. The Rfc unit is converted first into units of $\mathrm{m}^{3} / \mathrm{kg} /$ day, by multiplying the Rfc value with the adult inhalation default value of $20 \mathrm{~m}^{3}$ / day and dividing by the default value of the adult 70 $\mathrm{kg}^{14}$. Risk levels are expressed in numbers or decimal numbers without units. The risk level is said to be safe whenever its intake $\leq \mathrm{Rfc}$ is represented by $\mathrm{RQ} \leq 1$. The risk level is said to be unsafe when the intake values $\geq$ $R f c$ is expressed by $R Q \geq 1^{15}$.

\section{FINDING}

Table 1. The pattern of crystal silica dust exposure in production workers

\begin{tabular}{|l|l|l|l|l|}
\hline & $\begin{array}{l}\text { Concentration of } \\
\mathbf{c}-\text { silica dust }\end{array}$ & $\begin{array}{l}\text { Respiratory rate } \mathbf{( m}^{3} \\
/ \mathbf{h})\end{array}$ & $\begin{array}{l}\text { Intake of c-silica dust } \\
\mathbf{( m g} / \mathbf{m 3} / \mathbf{d a y})\end{array}$ & Risk Quostion \\
\hline Mean & 0,0686 & 0,6572 & 0,00192 & 2,2343 \\
\hline Median & 0,0540 & 0,6600 & 0,00129 & 1,5017 \\
\hline Mode & 0,0540 & 0,66 & 0,00024 & 0,0459 \\
\hline Std. Deviation & 0,0704 & 0,0218 & 0,00260 & 3,0251 \\
\hline Range & 0,4387 & 0,10 & 0,01668 & 19,391 \\
\hline Minimum & 0,0078 & 0,59 & 0,00004 & 0,0456 \\
\hline Maximum & 0,4466 & 0,69 & 0,01672 & 19,4365 \\
\hline
\end{tabular}


From table 1 the research results can be seen that the concentration of crytaline silica dust at work ranged from $0.0078-0.4466 \mathrm{mg} / \mathrm{m}^{3}$ with an average of 0.0686 $\mathrm{mg} / \mathrm{m}^{3}$. The average respiration rate of workers is $0.6572 \mathrm{~m}_{3} /$ hour. Intake of silica dust based on exposure pattern and anthropometric data of worker ranged from $0,00004-0,01672 \mathrm{mg} / \mathrm{m}_{3} /$ day with average intake 0,00192. Risk level (RQ) ranged from 0,0456 - 19,4365 with value $R Q \geq 1$ equal to $42,6 \%$ from total respondent. Age of respondents in this study between $23-56$ years with an average age of 42.38 years. The working period ranges from $2-25$ years with an average of 18.06 years. Workers work for 8 hours per day with 1 hour break time to exit the workroom so that the effective hours of labor are in the workroom for 7 hours.

Tabel 2. Estimate the value of the risk level of chronic exposure to production workers

\begin{tabular}{|l|l|l|}
\hline Duration & Risk Quotient (RQ) & $\begin{array}{l}\text { Persentase } \\
\mathbf{( \% )}\end{array}$ \\
\hline \multirow{3}{*}{5 year } & $\mathrm{RQ} \leq 1$ & 51,1 \\
\cline { 2 - 3 } & $\mathrm{RQ} \geq 1$ & 48,9 \\
\hline \multirow{3}{*}{10 year } & $\mathrm{RQ} \leq 1$ & 42,6 \\
\cline { 2 - 3 } & $\mathrm{RQ} \geq 1$ & 57,4 \\
\hline \multirow{2}{*}{15 year } & $\mathrm{RQ} \leq 1$ & 34,0 \\
\cline { 2 - 3 } & $\mathrm{RQ} \geq 1$ & 66,0 \\
\hline \multirow{2}{*}{20 year } & $\mathrm{RQ} \leq 1$ & 29,8 \\
\cline { 2 - 3 } & $\mathrm{RQ} \geq 1$ & 70,2 \\
\hline
\end{tabular}

Tabel 2. shows that in the projection of exposure over the next 20 years an increase in the value of RQ $\geq$ 1 can be interpreted that there is an increased risk due to exposure to c-silica dust up to 20 years in the future.

\section{DISCUSSION}

Continuous exposure to c-silica dust can have both long-term and short-term effects ${ }^{16}$. The source of c-silica dust part production comes from raw materials in the form of clay and silica sand containing free silica that make ceramic to be harder and stronger ${ }^{12}$. The heating process in the production process to a temperature of about $1200{ }^{\circ} \mathrm{C}$ will also form another fraction of the more reactive c-silica dust. The level of c-silica dust has a uniform distribution throughout the workplace with an average grade of $0.068 \mathrm{mg} / \mathrm{m}_{3}$. The temperature used in the production process will also affect the convection and radiation to the temperature rise of the work environment. The working environment temperature ranges from $31.3-36.6{ }^{\circ} \mathrm{C}$ which makes the c-silica dust become drier and lighter so it is easily carried by the airflow present in the work environment and can expand the spread of the dust. Silicosis is still present in workers who die affected by exposure to silica dust between $0.05-0.1 \mathrm{mg} / \mathrm{m}_{33}$. From the result of the measurement of c-silica dust in the working environment by using personal sampler on each respondent got result that exceeds limit value based on Indonesia regulation (Ministry of Manpower and Transmigration No. PER.13 / MEN / X / 2011) amounted to 55.3\%. The value of concentration is very influential on the value of intake in workers the higher the concentration of dust c-silica in the work environment the higher the value of the intake so that the value of risk will also increase ${ }^{1}$.

Chest radiography can be used to assess the exposure of silica dust. The interpretation of the results of a thorax examination should be done using the radiographs of pneumoconiosis guidance from the $\mathrm{ILO}_{1}{ }^{3}$. Based on the calculation of risk values over the next 20 years based on table 2 there is an increased risk. This happens because exposure to c-silica dust is prolonged even further if not effectively controlled ${ }^{16}$.

\section{CONCLUSION}

From this study it can be concluded that $42.6 \%$ of respondents mempuyai unsafe risk level of exposure to c-silica dust so potentially health problems due to exposure to c-silica dust. Based on the estimated calculation of chronic exposure risk, the risk level tends to increase to the next 20 years.

\section{Conflict of Interest: None}

\section{Source of Funding: Self}

Ethical Clearance: This study was approved by Health Research Ethics Committee, Faculty of Public Health, Airlangga University

\section{REFERENCE}

1. Chen, W. et al.(2012) "Long-term exposure to silica dust and risk of total and cause-specific mortality in Chinese workers: A cohort study," PLoS Medicine, 9(4). doi: 10.1371/ journal.pmed.1001206.

2. "IARC Working Group on the Evaluation of Carcinogenic Risks to Humans: Silica, Some Silicates, Coal Dust and Para-Aramid Fibrils. Lyon, 15-22 October 1996." (1997) IARC monographs 
on the evaluation of carcinogenic risks to humans / World Health Organization, International Agency for Research on Cancer, 68, hal. 1-475.

3. Office of Environmental Health Hazard Assessment (2005) "Chronic Toxicity Summary."

4. Salawati, L. (2017) "Silikosis," JURNAL KEDOKTERAN SYIAH KUALA Volume, 17(April), hal. 20-26.

5. Rinawati, P. (2015) "Coal Worker " S Pneumoconiosis," 4, hal. 49-56.

6. Department Of Health And Human Services, Centers for Disease Control and Prevention National Institute for Occupational (2002) "Health effects of occupational exposure to respirable crystalline silica," Washington, DC: National Institute for Occupational Safety and Health, 129.

7. PER.13/MEN/X/2011 (2011) "Peraturan Menteri Tenaga Kerja Dan Transmigrasi," Peraturan Menteri Tenaga Kerja Dan Transmigrasi.

8. Services, H. (1998) "Toxicological Profile," (205). doi: $h t t p: / / d x . d o i . o r g / 10.1155 / 2013 / 286524$.

9. Suhariyono, G., Bunawas dan Makhsun (2006) "ANALYSIS OF FREE SILICA ( $\mathrm{SiO} 2$ ) IN RESPIRABLE DUST WITH METHOD OF NIOSH 7500," Prosiding Seminar Nasional Keselamatan, Kesehatan, dan Lingkungan II, Pusat
Tenaga, (December 2006), hal. 0-15.

10. National Institute for Occupational Health and Safety (2003) "SILICA , CRYSTALLINE , by XRD ( filter redeposition )," NIOSH Manual of Analytical Methods, 7.

11. Louvar FL and Louvar BD (1998).Eenvironment Risk Analysis Volume 2. New Jersey: Prentice Hall PTR.

12. Bakri, R., Utari, T. dan Sari, P. (2008) "Koalin Sebagai Sumber $\mathrm{SiO} 2$ Untuk Pembuatan Katalis Ni/ SiO2: Karakterisasi Dan Uji Katalis Pada Hidrogenasi Benzena Menjadi Sikloheksana," Makara, Sains, 12(1), hal. 37-43.

13. Siswanto (1996) Penyakit Akibat Debu Silika. Surabaya: Balai Hiperkes dan Keselamatan Kerja Jawa Timur Departemen Tenaga Kerja.

14. U.S. Environmental Protection Agency (1994) "Methods for derivation of inhalation reference concentrations and application of inhalation dosimetry,". doi: EPA/600/8-90/066F.

15. P2PL KEMENKES (2011) Pedoman Analisis Resiko Kesehatan Lingkungan. Jakarta: KEMENKES RI.

16. Suma'mur (2014) Higene Perusahaan dan Kesehatan Kerja (HIPERKES). 2 ed. Jakarta: CVSagung Seto. 